\title{
EFFECT OF JOB SATISFACTION ON JOB PERFORMANCE, WITH QUALITY OF WORK LIFE AS MODERATING AMONG JORDANIAN HOTELS: A PILOT STUDY
}

\author{
Bandar Ersan Alown ${ }^{1}$, Mahadzirah Binti Mohamad ${ }^{2}$, Fazida Karim ${ }^{3}$ \\ 1 Faculty Economic, Universiti Sultan Zainal Abadin (UNISZA), Malaysia. \\ Email: bandaraloun@gmail.com \\ 2 Faculty Economic, Universiti Sultan Zainal Abadin (UNISZA), Malaysia \\ Email: mahadzirahmd@unisza.edu.my \\ 3 Faculty Economic, Universiti Sultan Zainal Abadin (UNISZA), Malaysia \\ Email: fazidakarim@unisza.edu.my
}

\section{Article Info:}

Article history:

Received date:23.01.2020

Revised date: 05.02.2020

Accepted date: 06.02.2020

Published date: 13.03.2020

\section{To cite this document:}

Alown, B. E., Mohamad, M., \& Karim, F. (2020). Effects of Job Satisfaction on Job Performance, with Quality of Work Life as Moderating among Jordanian Hotels: A Pilot Study. Journal of Tourism, Hospitality and Environment Management, 5 (18), 52-66.

DOI: $10.35631 /$ JTHEM.518005.

\begin{abstract}
:
Employees in the hotel industry are the key personnel who contribute to giving guests the satisfactory experience they expect. Therefore, it is important that every employee strives to improve his/her job. The purpose of this study is to examine the influence of job satisfaction, leadership style, and organisational structure on job performance, with the moderating role of quality of work-life among employees working in Jordanian hotels. The study explores the perceptions of employees working in five-star hotels in Jordan in order to verify the validity and reliability of the study instrument. The study was applied to a small sample, and SPSS analysis software was used. The study validated the reliability of the instrument in conducting a preliminary study, obtaining reasonable normality and highly reliable coefficients of measures (0.9270.986). The study validated the effectiveness of the instrument that examined different specific antecedents of job performance.
\end{abstract}

Keywords:

Jordan, Job Performance, Job Satisfaction, Five-Star Hotels, Quality of Work Life

\section{Introduction}

Tourism is a significant sector of many economies and often the mainstay of the economy of some developing countries. While the hotel segment is a crucial part of any tourism industry anywhere. In the hotel segment, the employees are crucial in influencing the quality of the service delivery, whether as front-line counter staff or as room service or maintenance 
personnel. staff or back-line staff or behind these scenes as room service, food and beverage or maintenance personnel (Chen, 2013).

The hospitality industry is diverse and encompasses activities ranging from exclusively catering to catering as well as accommodation, sole trader catering to the government and who received subsidies and whose activities are government-controlled; single hotel operations to chain operators, and eating for pleasure, to eating to survive, The hotel industry is therefore complex and heterogeneous (Øgaard et al., 2008) with its core offerings being accommodation, food and beverage. Employees are entrusted to carry out their roles according to the standard set via the organisation. The role of managing is to formulate a set of service standard perceived to meet the customers' expectations. Likewise, it is the management's responsibility to help service employees to develop interpersonal skills (Haksever, 2000) that can help them in handling the service encounters and processes satisfactorily. On the other hand, employees are responsible to carry out the service delivery according to the specifications set by the management from their own perceptions of service quality. To complete the service delivery process, customers, who are the ultimate beneficiaries, would evaluate the service quality rendered from their subjective perspective of quality service.

There are some factors that can affect the satisfaction of job across industries and countries such as relationship with supervisors and co-workers, training and development, and wage structure (Rogelberg et al., 2010; Amin et al., 2014; Tang et al., 2014). In hotel industry, Chiang et al., (2014) mentioned that employees are experience the greatest satisfaction when their jobs offer them reward, training and good organisational structure. Based on Grant and Parker (2009), social support such as organisation and supervisor support is one of the expected influential factors that impact satisfaction of job. Therefore, if employees perceive that these expectations are met, it will improve employee satisfaction level and have an optimistic influence on the performance of jobs.

Moreover, Damayanthi et al. (2014) pointed to the close relationship between the way an organisation is structured and manager's leadership style and the level of employee's satisfaction with his/her job. Tran and Tian (2013) defined organisational structure as "the allocation of work roles and administrative mechanisms to control work activities and the hierarchical relations among members of the organisation." In addition, leadership style includes a process of influencing by the leader in governing the behaviour of subordinates towards attaining the goals of the organisation (Ilyas \& Abdullah, 2016). Considering all these factors, this current study investigated the impact of organisational structure and leadership style on the satisfaction of jobs.

The tourism sector in Jordan is still generally not fully developed particularly in terms of work conditions and job environment, for owners of the business and also for employees. In fact, hotels in Jordan need to pay more attention to the issue of job satisfaction and job performance among their employees. By doing so, Jordan can lead the tourism industry in the region. The issue of job satisfaction and job performance can greatly impact the country's revenue and economic progress, which can assist in the development and flourish of the country's general aspects of life (Ali \& Ali, 2010).

Therefore, this study's findings are expected to contribute to the relevant literature that focuses on the effects of job satisfaction, leadership style, and organisational structure on job performance, with the moderating role of quality of work life among employees working in Jordanian hotels. 


\section{Job Performance and Job Satisfaction}

Achievement of high-level performance through productivity and efficiency has dependably been an authoritative objective of high need. With a specific end goal to do that profoundly fulfilled work constrain is a completely need for accomplishing an abnormal state of execution progression of an organisation. Satisfied workers lead to an extent job performance, at that point works harder and better. Subsequently every organisation attempts to make a satisfied work force to function the prosperity of the organisation. In any case, the organisation occupation relies upon efficient and performance of individual workers of the organisation. In this way, every organisation puts a significant dependence on their individual performance to increase high profitability in the organisation. Employee effort is a critical factor that decides an individual performance at work. At the point when an employee feels satisfied about the work that he/she is inspired to do grater push to the job performance. At that point it tends to build the overall performance of the organisation. As it were, a satisfied individual employee with an effort and duty are vital for the achievement of the organisation. It is the general understanding that job satisfaction is a mentality towards work. At the end, satisfaction of job is an effective or enthusiastic reaction toward several features of one's job. A person with high state of satisfaction in jobs holds a positive conducts towards his/her work, while a person who is unsatisfied with his /her work holds negative mentalities about the work (Pushpakumari, 2008).

As indicated by Avolio et al., (2009) A pleasurable or positive enthusiastic state resulting from the appraisal of one's work or job experience. The satisfaction in job is a result of workers' impression of how well their job gives those critical things. The satisfaction in job is additionally characterized as reintegration of effect created by person's view of satisfaction of his needs in connection to his work and its surrounding Organ and Hammer called attention to that The satisfaction in job represent a complex gathering of insight, feeling and inclinations (Chiu \& Tsai, 2007). From the definitions, plainly the satisfaction in job is an undetectable variable. Hence, there is no positive method for estimating job satisfaction. As, there are several ways that can recognized from the current literature. A survey can be utilized to measure the satisfaction in job. In this method, it is estimated the satisfaction with different measurements or dimension of the job and sum of all satisfaction scores will be taken as the general satisfaction.

Any job-related factor can impact a person's level in the satisfaction of job or dissatisfaction. There are various components that impact the satisfaction in job. The significant ones can be abridged by reviewing the measurements of satisfaction in job. The work itself, advancements, supervision, workgroup, and working conditions (Avolio et al., 2009).

The job satisfaction has some critical managerial ramifications. As if the satisfaction in job is high, the workers will perform better. Then again, if the satisfaction in job is low, there will be working issues in performance. In looking at the results of job satisfaction, it is critical to breakdown the examination into a progression of a particular factor. They are profitability, turnover, non-appearance and different impacts (accidents, grievances, physical and psychological health). The main target of reward programs is drawing in qualified people to join the organisation to keep workers coming to work and to push workers to accomplish a high level of execution. In spite of the fact that the prizes are given by the organisation, they are assessed by the person. To the degree that the prizes are sufficient and impartial, the individual accomplishes a level of satisfaction. The prizes can be extensively classified in to two groups, to be specific intrinsic and extrinsic rewards. Intrinsic are psychological prizes that 
are experienced specifically by an individual (Gibson et al., 1991). These are characterized as prizes that are a piece of the work itself.

It had likewise characterized as psychological reward that is experienced specifically by an employee (Iacobucci \& Churchill, 2010). Extrinsic rewards are given by an outside operator, for example, manager or work gathering. These prizes had been characterized as prizes outer to the job. Pay, advancements, relational connections, status and incidental advantages are a portion of the cases for the extrinsic rewards. Obligation, accomplishment, self-rule, selfawareness, challenge, finish work, and criticism qualities of the activity are some inherent prizes. Execution especially relies upon recognition, qualities and dispositions. There seem, by all accounts, to be such a large number of variables affecting the job execution that is relatively difficult to understand them. Performance is characterized as a component of individual capacity and ability and performance in a given circumstance. In the short run, employee's aptitudes and capacities are moderately steady. Consequently, with the objectives of the study, the analyst characterizes the execution regarding exertion reached out to the activity of a representative. Effort is an interior power of a person which makes him/her to work energetically when employees are happy and satisfied with their job and their needs are met, they build up a connection to work or we say that they attempt to perform better (Judge et al., 2001).

Evans and Jack demonstrated that employee satisfaction positively effects on market performance, which was dissected through income per share, and market performance significantly affects financial performance (Evans \& Jack, 2003). It was discovered that the higher return on assets (ROA) and higher income per share were emphatically associated with higher job satisfaction. Beside the effect of job satisfaction on work performance, the converse impact likewise must be studied, i.e. the presence of the effect of organisation accomplishment on workers' satisfactions in job. As it may ought to be noticed that the level of identification with organisational achievement is essentially littler and considerably less inspiring in comparing with individual achievement, which is regularly, even definitely, followed by various rewards (Benjamin et al., 2003).

\section{Job Satisfaction and Leadership Style}

Another factor that influences job satisfaction across industries and countries is leadership style (Saleem, 2015; Masa'deh, 2016). For example, Abdelhafiz et al., (2016) found strong linkages between the different leadership styles and job satisfaction. However, there are inconsistent findings showed in previous studies (Alonderiene \& Majauskaite, 2016; Al-Ababneh, 2013). Thus, this study will investigate the link between leadership style and job satisfaction among employee in Jordan hotel.

Styles of leadership can affect work quality (Nanjundeswaraswamy \& Swamy, 2014), while work life of high quality is crucial for businesses in sustaining their attraction and in keeping their employees. There as on behind the quality of work life is to cause a work environment that is appropriate for both staff and production (Nazem \& Entezari, 2014). The quality of work life comprises the process that includes the involvement of all members of business in their organisation's decision making using certain open, communicative channels.

The most commonly practiced style of leadership among hotels is the dictatorial style of leadership, and such a style has been popular due to the volatility of this industry. Further, seeing that this leadership style has been so embedded in the industry, changes to another style, namely the participative leadership style, are challenging (Mullins, 1998). 
Managers of hotel establishments could offer motivators of numerous kinds to the employees as this contributes to improved leadership or job satisfaction. Thus, leadership styles become crucial tools in creating motivated employees, and this plays a crucial role in the achievement of the employees' objectives that the organisation has set (Kavanaugh \& Ninemeier, 2007).

\section{Job Satisfaction and Organisational Structure}

Job satisfaction is a widely accepted predictor of productivity (Robbins, 2009). Employees are the crucial asset of any organisation especially in building its competitive advantage. According to service profit chain theory, employee satisfaction can improve quality of service which results in high customer satisfaction and able make the organisation profitable. Based on previous research, organisational structure is one of the reasons for employee satisfaction (Thomas, 2015; Picardi, 2017). Job satisfaction and effectiveness level experienced by individuals are impacted by organisation structure, considering that organisation structure involves the approved work-related behavior pattern intentionally established to achieve the organisational goals.

Masa'deh, (2016) suggest future study can further investigated others organisational factor such as organisational structure that may enhance job satisfaction. Moreover, the impact of organisational structure on job satisfaction should also be studied further in the context of hotels in Jordan because the available findings on such relationship are mixed. Thus, the effect of organisational structure on job satisfaction need to be further investigates. Another factor that influences job satisfaction across industries and countries is leadership style (Saleem, 2015; Masa'deh, 2016). For example, Abdelhafiz et al., (2016) found strong linkages between the different leadership styles and job satisfaction. However, there are inconsistent findings showed in previous studies (Alonderiene \& Majauskaite, 2016; Al-Ababneh, 2013).

Srivastava (2016) defined organisation structure as "the arrangement of task, interrelations of various departments and levels of authority to achieve co-operation of efforts, delegation of authority and effective communication along the scalar chain of command." Examples would include formality, option, hierarchy, and centralization, which are organisational structure components that influence the enhancement of work life quality (Salimbahrami et al., 2015). Besides that, Hamideh et al. (2015) indicated that centralized organisational structure which provided authority to employees to design jobs might meet the expectations of employees and increase their quality of work life. These studies indicated that an organisation should design a suitable structure that can increase the quality of work life especially in the hotel industry. This is because hospitality organisations are complex entities which need to coordinate a number of services that make up the task environment that must be properly organized (Øgaard et al., 2008).

\section{Job Satisfaction and Quality of Work Life}

The relationship between Quality of work Life (QWL) and Job Satisfaction was examined by Othman \& Mok, (2009) and as found, more than half of the respondents (54.8\%) viewed the QWL programme as good while the level of job satisfaction was reported to be moderate. There was generally a substantial relationship between QWL programme and job satisfaction.

In looking into the relationship between job satisfaction and quality of work life in the service sector, Babu \& Ramesh, (2013) concluded a strong relationship between quality of work life and job satisfaction.

At medical centers in Southern Taiwan, the linkage between job stress, job satisfaction, and quality of work life for an aesthetic nurse was scrutinized by using the cross-sectional study 
design. As indicated by the authors, the significant factors impacting the quality of work life among anesthetic nurses are the intent to quit, overall job satisfaction, habits of exercise and possessing a subspecialty.

In investigating the impact of job satisfaction on the quality of work life, Yadav \& Khanna, (2014) documented the highly satisfactory performance of State Bank of India as opposed to the quality of work life provided to the employees.

A study by Owolabi, (2015) revolved around the impact of job satisfaction on the quality of work life, and the author found a significant impact of work-family conflict and job satisfaction on the quality of work life. Meanwhile, sex differences in work-family conflict, job satisfaction, and work life quality, showed no significance.

According to Bin, (2015) in his study aims to discover the factors that contribute to a satisfied employee. For this purpose, several factors were studied, and they are job fit, good communication, appreciation and clear objectives. The organisation and individual role in employee satisfaction were also scrutinized. Job performance as among the organisation's main success factors was examined. Employee satisfaction and its linkage to performance findings were explained.

\section{Theoretical Framework}

Job performance dedicated studies have brought forward several theories in their attempt to shed light on the job performance relationship. In particular, there are four theories proposed: Transformational leadership theory, Social Exchange Theory, resource-based view, and Service-Profit Chain. The above theories also contributed to the development of the present study's research framework.

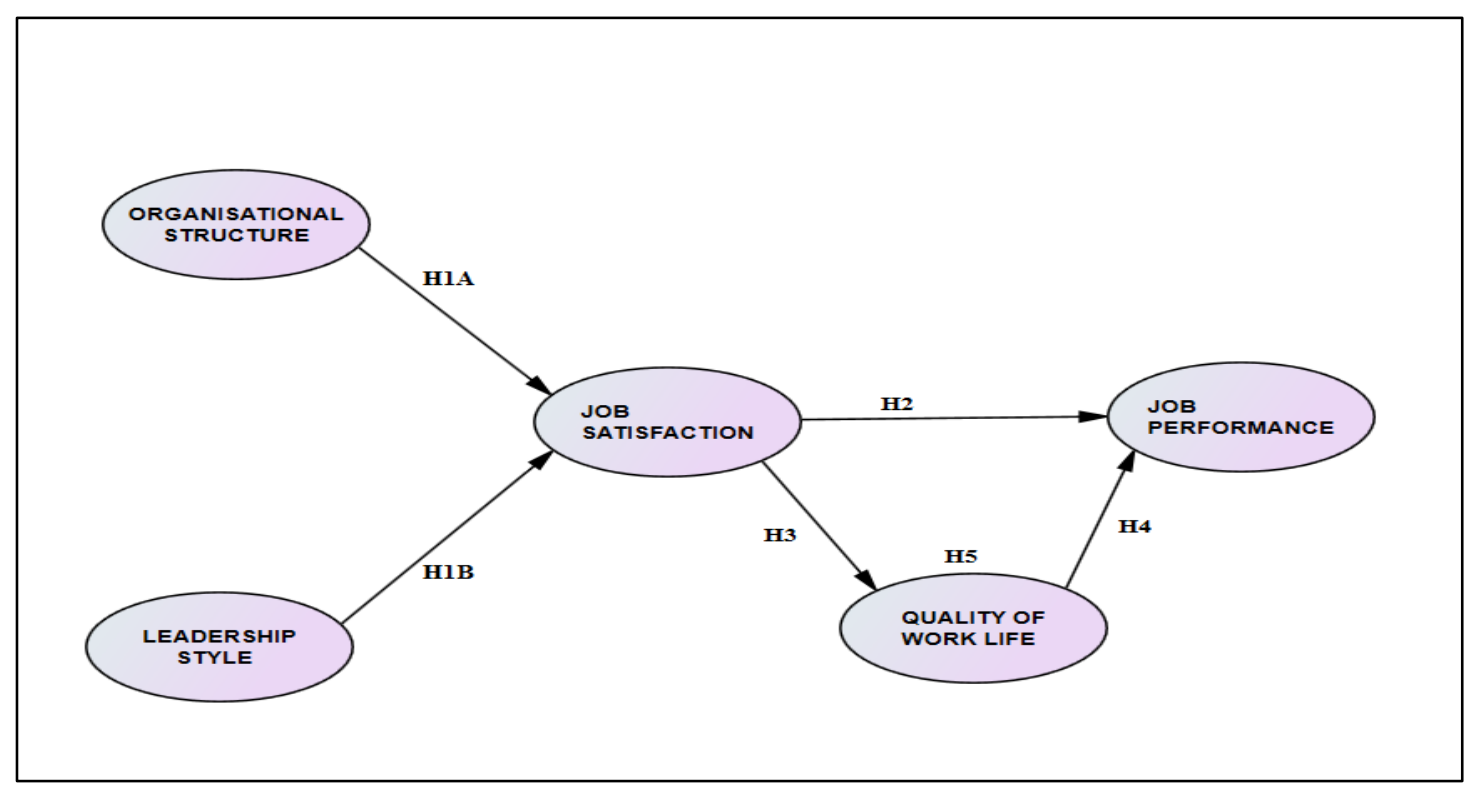

Figure 1: Theoretical Framework

\section{Data Collection}

As stated by Zikmund et al., (2010) a research design entails a master plan outlining the methods and procedures that are to be employed in the gathering and analyses of data. Accordingly, a quantitative method has been selected for this study, while the questionnaire has been chosen to be the primary data gathering tool. In this study, the questionnaire is 
constructed and tested using a pilot study. Then, the finalized questionnaire deemed fit for the actual study.

\section{Data Instrument}

For the purpose of this study, self-administered questionnaires distributing and were then retrieved to gather the primary data. There are a number of benefits associated with this method of data gathering. Firstly, this instrument of data gathering enables the researcher to exhaustively summarize the attitudes, thoughts as well as the behaviour of the sample. At the same time, considering that these self-administered questionnaires being distributable to significant number of respondents, this method is efficient in terms of cost and time. Thirdly, the distribution of questionnaires is simple to do and therefore, it is less prone to errors. Lastly, questionnaires support anonymity and thus, the respondents would feel sufficiently comfortable in expressing their opinions as well as experiences (Hayes, 2017).

Also, the questionnaire for this study uses a 10-point rating scale ranging from 1, "strongly disagrees", to 10, "strongly agrees". Awang (2012) mentions the appropriate range of a questionnaire should be in the interval from 1 to 10 . The author claims that the interval scale is a continuous score and meets the requirement for using parametric statistical analysis. Numerous previous researches have employed the 10-point rating scale in structural equation melding (Chen, 2013; Chou \& Kim, 2009; Curşeu et al., 2007; Delahaij, Gaillard, \& van Dam, 2010).

The questionnaire items were including on the basis of the conceptual finding and explanation reviewed in literature that were adopted and adapted to suit the objective of the study, as suggested by Zikmund et al., (2013).

Table 1: Measurement Variables

\begin{tabular}{|c|c|c|c|}
\hline Construct & No. of items & Adapted from & Scale \\
\hline Job performance & 4 & $\begin{array}{l}\text { Naser \& Shokouh, } \\
2016\end{array}$ & $1-10$ \\
\hline Quality of work life & 8 & Lan et al., 2015 & $1-10$ \\
\hline Job satisfaction & 5 & Hassi, 2018 & $1-10$ \\
\hline Leadership style & 5 & $\begin{array}{l}\text { Sanda \& Dodua, } \\
2017\end{array}$ & $1-10$ \\
\hline $\begin{array}{l}\text { Organisational } \\
\text { structure }\end{array}$ & 5 & valaei, 2017 & $1-10$ \\
\hline
\end{tabular}

\section{Pilot Study}

The pilot study was performed to develop, to determine the reliability of measures and to calculate the appropriate size of the final sample. Before conducting the actual study, a pilot test had validated the survey instrument.

Throughout the pilot study process, the researcher assisted the respondents in completing the questionnaire in term of wording and meaning of the items. During the pilot test, the period to answer the questions by the respondents also had been considered. The average times that were taken by the respondents were about 15-20 minutes. After conducting a pilot test, an exploratory factor analysis (EFA) was run to identify how many factors of job performance, quality of work life, job satisfaction, leadership style and organisational structure were needed to represent the data. Next, detailed explanation of the data reduction procedure using the EFA in the SPSS is presented. 


\section{Sample of The Pilot Study}

In this study, a pilot test was conducted among 200 front line employee selected from Jordanian hotel industry located in Amman (Fairmount, Intercontintal Amman, Grand Millennium and Kempinski) and Aqaba (Oryx, Tala Bay and Isrotel Agamin). The reason for selecting respondents from this location is because it has a similar background with the actual respondents in the 21 hotels that were selected for the actual study. The data collected in the pilot test used the same approach to the one used for the real field study.

\section{Statistical Analysis of The Pilot Study}

Exploratory factor analysis is a statistical approach that can be used to achieve two primary results; data summarizing and data reduction (Tabachnick \& Fidell, 2013). According to the authors, data summarizing aims to locate appropriate structure of the research variables under the specific logic factors. Whereas, data reduction is a process used to remove uncorrelated items and reduces the number of items within each variable. In other words, EFA is a procedure used to identify, reduce, and organize a large number of questionnaire items into a specific construct for the independent variable in the study.

The procedure is first conducted with a Kaiser-Meyer-Olkin (KMO) test and Bartlett's Test of Sphericity to verify if the data set was suitable for factor analysis. The purpose of both tests is to measure the sampling adequacy to determine the factorability of the matrix or data set as a whole (Hair et al., 2014). If Bartlett's Test of Sphericity is substantial and significant, and the $\mathrm{KMO}$ measure is higher than 0.50 , it can be assumed that the factorability dataset does exist (Pallant, 2010).

Next, the Principal Component Analysis (PCA) extraction method with the Varimax Rotation was used to extract the underlying factors in this study. The extraction of factors is examined using PCA to identify the number of factors to be retained while Varimax Rotation is applied as it is the most popular and suitable orthogonal factor rotation method because it can clarify the analysis of factors (Hair et al., 2014). Moreover, the authors claimed that the varimax orthogonal technique is proven a successful analytic approach to obtain orthogonal rotation of factors. The items that load higher than 0.6 are retained while low loading items are dropped. In general, Tabachnick \& Fidell (2013) suggested that higher factor loading is considered better, and typically loadings below 0.30 are not interpreted. Also, the author demonstrated that as a general rule of thumb, loadings above 0.71 are excellent, 0.63 very good, 0.55 good, 0.45 fair, and 0.32 poor. Next, detailed explanation of the result is discussed below.

\section{Result for Pilot Study}

Before conducting the EFA, the reliability test was conducted for internal consistency using Cronbach's alpha. Nunnally (1978) suggested that an alpha of 0.70 as the minimum acceptable standard for demonstrating internal consistency. The Table 2 below illustrated all the values of Cronbach's Alpha are above cut-off point. The value for job performance, quality of work life, job satisfaction, leadership style, and organisational structure are 0.93, 0.94, 0.92, 0.98, and 0.94 respectively. Thus, these results confirm that all the factors have good reliability and internal consistency of the items. 
Table 2: Summary of Pilot Test Reliability Results

\begin{tabular}{clrc}
\hline No & Construct & $\begin{array}{r}\text { No. of } \\
\text { Items }\end{array}$ & Cronbach's Alpha \\
\hline 1. & Job Performance & 4 & 0.931 \\
2. & Quality of Work Life & 8 & 0.948 \\
3. Job Satisfaction & 5 & 0.927 \\
4. $\quad$ Leadership Style & 5 & 0.986 \\
5. Organisational Structure & 5 & 0.949 \\
\hline
\end{tabular}

\section{Result for Job Performance}

The PCA with Varimax was performed for four items of the job performance construct. Based on Table 3 as presented below total one factors were extracted with an eigenvalue of more than one explaining $82.86 \%$ of the total variance.

Table 3: The Total Variance Explained for Job Performance

\begin{tabular}{ccccccc}
\hline Component & \multicolumn{3}{c}{ Initial Eigenvalues } & \multicolumn{2}{c}{$\begin{array}{c}\text { Extraction Sums of Squared } \\
\text { Loadings }\end{array}$} \\
\cline { 2 - 7 } & Total & $\begin{array}{c}\text { \% of } \\
\text { Variance }\end{array}$ & $\begin{array}{c}\text { Cumulative } \\
\text { \% }\end{array}$ & Total & $\begin{array}{c}\text { \% of } \\
\text { Variance }\end{array}$ & $\begin{array}{c}\text { Cumulativ } \\
\text { e \% }\end{array}$ \\
\hline 1 & $\mathbf{3 . 3 1 5}$ & $\mathbf{8 2 . 8 6 9}$ & $\mathbf{8 2 . 8 6 9}$ & $\mathbf{3 . 3 1 5}$ & $\mathbf{8 2 . 8 6 9}$ & $\mathbf{8 2 . 8 6 9}$ \\
2 & $\mathbf{3 0 2}$ & $\mathbf{7 . 5 5 1}$ & $\mathbf{9 0 . 4 2 0}$ & & & \\
3 & .231 & $\mathbf{5 . 7 6 4}$ & $\mathbf{9 6 . 1 8 4}$ & & & \\
4 & $\mathbf{. 1 5 3}$ & $\mathbf{3 . 8 1 6}$ & $\mathbf{1 0 0 . 0 0 0}$ & & & \\
\hline
\end{tabular}

Extraction Method: Principal Component Analysis.

Next, the rotated component matrix is shown in Table 4 Based on the table, the first factor consists of four items loaded on component one. After the deletion of items less than 0.6, all the job performance items were with acceptable communality values, ranging from 0.898 to 0.929. As a general rule of thumb indicated by Tabachnick \& Fidell (2013), loadings above 0.63 are very good.

Table 4: The Rotated Component Matrix and Items Retained in Job Performance

\begin{tabular}{clc}
\hline No. & \multicolumn{1}{c}{ Items } & $\begin{array}{c}\text { Compone } \\
\text { nt } \\
1\end{array}$ \\
\hline JP1 & My work efficiency is much higher than average. & .929 \\
JP2 & $\begin{array}{c}\text { My standards of work quality are higher than the formal } \\
\text { standards for this job. }\end{array}$ & .898 \\
JP3 & My work meets expectations of my manager. & .908 \\
JP4 & I strive for higher quality work than required. & .906 \\
\hline
\end{tabular}

Extraction Method: Principal Component Analysis.

\section{Result for Quality of Work Life}

The PCA with Varimax was performed for eight items of the quality of work life construct. Based on Table 5 as presented below total one factors were extracted with an eigenvalue of more than one explaining $73.30 \%$ of the total variance. 
Table 5: The Total Variance Explained for Quality of Work Life

\begin{tabular}{ccccccc}
\hline $\begin{array}{c}\text { Compon } \\
\text { ent }\end{array}$ & \multicolumn{3}{c}{ Initial Eigenvalues } & \multicolumn{2}{c}{$\begin{array}{c}\text { Extraction Sums of Squared } \\
\text { Loadings }\end{array}$} \\
\cline { 2 - 7 } & Total & $\begin{array}{c}\text { \% of } \\
\text { Variance }\end{array}$ & $\begin{array}{c}\text { Cumulativ } \\
\text { e \% }\end{array}$ & Total & $\begin{array}{c}\text { \% of } \\
\text { Variance }\end{array}$ & $\begin{array}{c}\text { Cumulativ } \\
\text { e \% }\end{array}$ \\
\hline $\mathbf{1}$ & $\mathbf{5 . 8 6 4}$ & $\mathbf{7 3 . 3 0 1}$ & $\mathbf{7 3 . 3 0 1}$ & $\mathbf{5 . 8 6 4}$ & $\mathbf{7 3 . 3 0 1}$ & $\mathbf{7 3 . 3 0 1}$ \\
$\mathbf{2}$ & $\mathbf{4 4 8}$ & $\mathbf{5 . 6 0 0}$ & $\mathbf{7 8 . 9 0 0}$ & & & \\
$\mathbf{3}$ & $\mathbf{4 1 5}$ & $\mathbf{5 . 1 8 7}$ & $\mathbf{8 4 . 0 8 8}$ & & & \\
$\mathbf{4}$ & $\mathbf{. 3 6 1}$ & $\mathbf{4 . 5 1 7}$ & $\mathbf{8 8 . 6 0 5}$ & & & \\
$\mathbf{5}$ & $\mathbf{. 3 0 1}$ & $\mathbf{3 . 7 6 5}$ & $\mathbf{9 2 . 3 7 0}$ & & & \\
$\mathbf{6}$ & $\mathbf{. 2 6 2}$ & $\mathbf{3 . 2 7 5}$ & $\mathbf{9 5 . 6 4 5}$ & & & \\
7 & $\mathbf{. 1 9 4}$ & $\mathbf{2 . 4 2 9}$ & $\mathbf{9 8 . 0 7 4}$ & & & \\
$\mathbf{8}$ & $\mathbf{. 1 5 4}$ & $\mathbf{1 . 9 2 6}$ & $\mathbf{1 0 0 . 0 0 0}$ & & & \\
\hline
\end{tabular}

Extraction Method: Principal Component Analysis.

Next, the rotated component matrix is shown in Table 6 Based on the table, the first factor consists of eight items loaded on component one. After the deletion of items less than 0.6, all the quality of work life items was with acceptable communality values, ranging from 0.832 to 0.874. As a general rule of thumb indicated by Tabachnick \& Fidell (2013), loadings above 0.63 are very good.

Table 6: The Rotated Component Matrix and Items Retained in Quality of work Life

\begin{tabular}{llc}
\hline No. & \multicolumn{1}{c}{ Items } & $\begin{array}{c}\text { Component } \\
1\end{array}$ \\
\hline QWL & I do my best to stay healthy and fit. & .868 \\
$\mathbf{1}$ & & \\
QWL & I am satisfied with what I'm getting paid for my work. & .854 \\
$\mathbf{2}$ & & .856 \\
QWL & I feel that my business is secure. & .832 \\
$\mathbf{3}$ & & .832 \\
QWL & My business does well for my family. & .863 \\
$\mathbf{4}$ & & \\
QWL & My place of work is collegial. & .874 \\
$\mathbf{5}$ & & \\
QWL & I have enough time away from work to enjoy other thing & .859 \\
$\mathbf{6}$ & in life. & \\
QWL & I feel appreciated at work. & .843 \\
$\mathbf{7}$ & & \\
QWL & I feel that my work allows me to realize my full potential. & \\
$\mathbf{8}$ & & \\
\hline
\end{tabular}

\section{Result for Job Satisfaction}

The PCA with Varimax was performed for five items of the job performance construct. Based on Table 7 as presented below total one factors were extracted with an eigenvalue of more than one explaining $77.40 \%$ of the total variance. 
Table 7: The Total Variance Explained for Job Satisfaction

\begin{tabular}{ccccccc}
\hline $\begin{array}{c}\text { Compone } \\
\text { nt }\end{array}$ & \multicolumn{3}{c}{ Initial Eigenvalues } & \multicolumn{2}{c}{$\begin{array}{c}\text { Extraction Sums of Squared } \\
\text { Loadings }\end{array}$} \\
\cline { 2 - 7 } & Total & $\begin{array}{c}\text { \% of } \\
\text { Variance }\end{array}$ & $\begin{array}{c}\text { Cumulativ } \\
\text { e \% }\end{array}$ & Total & $\begin{array}{c}\text { \% of } \\
\text { Variance }\end{array}$ & $\begin{array}{c}\text { Cumulativ } \\
\text { e \% }\end{array}$ \\
\hline 1 & $\mathbf{3 . 8 7 0}$ & $\mathbf{7 7 . 4 0 7}$ & $\mathbf{7 7 . 4 0 7}$ & $\mathbf{3 . 8 7 0}$ & $\mathbf{7 7 . 4 0 7}$ & $\mathbf{7 7 . 4 0 7}$ \\
$\mathbf{2}$ & $\mathbf{3 8 9}$ & $\mathbf{7 . 7 7 3}$ & $\mathbf{8 5 . 1 8 0}$ & & & \\
3 & $\mathbf{. 2 9 3}$ & $\mathbf{5 . 8 6 0}$ & $\mathbf{9 1 . 0 4 0}$ & & & \\
4 & .257 & $\mathbf{5 . 1 4 4}$ & $\mathbf{9 6 . 1 8 4}$ & & & \\
5 & .191 & $\mathbf{3 . 8 1 6}$ & $\mathbf{1 0 0 . 0 0 0}$ & & & \\
\hline
\end{tabular}

Extraction Method: Principal Component Analysis.

Next, the rotated component matrix is shown in Table 8 Based on the table, the first factor consists of five items loaded on component one. After the deletion of items less than 0.6, all the job satisfaction items were with acceptable communality values, ranging from 0.865 to 0.898. As a general rule of thumb indicated by Tabachnick \& Fidell (2013), loadings above 0.63 are very good.

Table 8: The Rotated Component Matrix and Items Retained in Job Satisfaction

\begin{tabular}{llc}
\hline No. & Items & Component \\
& & $\mathbf{1}$ \\
\hline JS1 & $\begin{array}{l}\text { I am willing to work harder to help this company } \\
\text { succeed. }\end{array}$ & $\mathbf{8 8 8}$ \\
JS2 & I am proud to work for this hotel. & $\mathbf{8 9 8}$ \\
JS3 & I feel a strong sense of belonging to this organisation. & $\mathbf{. 8 8 2}$ \\
JS4 & I would refer a friend to come work at hotel. & $\mathbf{. 8 6 5}$ \\
JS5 & Overall, I am satisfied working at this hotel. & $\mathbf{. 8 6 6}$ \\
\hline
\end{tabular}

Result for Leadership Style

The PCA with Varimax was performed for five items of the leadership style construct. Based on Table 9 as presented below total one factors were extracted with an eigenvalue of more than one explaining $94.86 \%$ of the total variance.

Table 9: The Total Variance Explained for Leadership Style

\begin{tabular}{ccccccc}
\hline $\begin{array}{c}\text { Compon } \\
\text { ent }\end{array}$ & \multicolumn{3}{c}{ Initial Eigenvalues } & \multicolumn{2}{c}{$\begin{array}{c}\text { Extraction Sums of Squared } \\
\text { Loadings }\end{array}$} \\
\cline { 2 - 7 } & Total & $\begin{array}{c}\text { \% of } \\
\text { Variance }\end{array}$ & $\begin{array}{c}\text { Cumulativ } \\
\text { e \% }\end{array}$ & Total & $\begin{array}{c}\text { \% of } \\
\text { Variance }\end{array}$ & $\begin{array}{c}\text { Cumulativ } \\
\text { e \% }\end{array}$ \\
\hline 1 & $\mathbf{4 . 7 4 3}$ & $\mathbf{9 4 . 8 6 2}$ & $\mathbf{9 4 . 8 6 2}$ & $\mathbf{4 . 7 4 3}$ & $\mathbf{9 4 . 8 6 2}$ & $\mathbf{9 4 . 8 6 2}$ \\
2 & .149 & $\mathbf{2 . 9 8 5}$ & $\mathbf{9 7 . 8 4 8}$ & & & \\
3 & .066 & $\mathbf{1 . 3 2 8}$ & $\mathbf{9 9 . 1 7 6}$ & & & \\
4 & $\mathbf{. 0 3 2}$ & $\mathbf{. 6 4 5}$ & $\mathbf{9 9 . 8 2 1}$ & & & \\
5 & .009 & .179 & $\mathbf{1 0 0 . 0 0 0}$ & & & \\
\hline
\end{tabular}

Extraction Method: Principal Component Analysis.

Next, the rotated component matrix is shown in Table 10. Based on the table, the first factor consists of five items loaded on component one. After the deletion of items less than 0.6, all the leadership style items were with acceptable communality values, ranging from 0.957 to 0.988. As a general rule of thumb indicated by Tabachnick \& Fidell (2013), loadings above 0.63 are very good. 
Table 10: The Rotated Component Matrix and Items Retained in Leadership Style

No.

Items

Component

LS1 My Managers specify who is responsible for

.981

performance target.

$\begin{array}{lll}\text { LS2 My Managers clarify rewards. } & \mathbf{9 8 3}\end{array}$

$\begin{array}{lll}\text { LS3 } & \text { I tend to motivate my followers to seek different } & \mathbf{9 8 8}\end{array}$

LS4 I often find out what my employees want and try to $\quad .960$

LS5 My Managers draw attention toward failure in order to $\quad .957$ meet standards.

\section{Result for Organisational Structure}

The PCA with Varimax was performed for five items of the organisational structure style construct. Based on Table 11 as presented below total one factors were extracted with an eigenvalue of more than one explaining $84.09 \%$ of the total variance.

Table 11: The Total Variance Explained for Organisational Structure

\begin{tabular}{ccccccc}
\hline $\begin{array}{c}\text { Compone } \\
\text { nt }\end{array}$ & \multicolumn{3}{c}{ Initial Eigenvalues } & \multicolumn{2}{c}{$\begin{array}{c}\text { Extraction Sums of Squared } \\
\text { Loadings }\end{array}$} \\
\cline { 2 - 7 } & Total & $\begin{array}{c}\text { \% of } \\
\text { Variance }\end{array}$ & $\begin{array}{c}\text { Cumulativ } \\
\text { e \% }\end{array}$ & Total & $\begin{array}{c}\text { \% of } \\
\text { Variance }\end{array}$ & $\begin{array}{c}\text { Cumulativ } \\
\text { e \% }\end{array}$ \\
\hline 1 & $\mathbf{4 . 2 0 4}$ & $\mathbf{8 4 . 0 9 0}$ & $\mathbf{8 4 . 0 9 0}$ & $\mathbf{4 . 2 0 4}$ & $\mathbf{8 4 . 0 9 0}$ & $\mathbf{8 4 . 0 9 0}$ \\
2 & $\mathbf{. 5 8 8}$ & $\mathbf{1 1 . 7 6 1}$ & $\mathbf{9 5 . 8 5 1}$ & & & \\
3 & $\mathbf{1 2 2}$ & $\mathbf{2 . 4 3 4}$ & $\mathbf{9 8 . 2 8 5}$ & & & \\
4 & $\mathbf{. 0 5 6}$ & $\mathbf{1 . 1 2 0}$ & $\mathbf{9 9 . 4 0 5}$ & & & \\
5 & .030 & .595 & $\mathbf{1 0 0 . 0 0 0}$ & & & \\
\hline
\end{tabular}

Extraction Method: Principal Component Analysis.

Next, the rotated component matrix is shown in Table 12. Based on the table, the first factor consists of five items loaded on component one. After the deletion of items less than 0.6, all the organisational structure items were with acceptable communality values, ranging from 0.936 to 0.983 . As a general rule of thumb indicated by Tabachnick \& Fidell (2013), loadings above 0.63 are very good.

Table 12: The Rotated Component Matrix and Items Retained in Organisational Structure

\begin{tabular}{llc}
\hline No. & Items & $\begin{array}{c}\text { Component } \\
1\end{array}$ \\
\hline OS1 & $\begin{array}{l}\text { My company encourage knowledge sharing among } \\
\text { employees. }\end{array}$ & .697 \\
OS2 & $\begin{array}{l}\text { My company structure promotes collaborative rather } \\
\text { than individualistic working behaviour. }\end{array}$ & .964 \\
OS3 & $\begin{array}{l}\text { My company structure facilities knowledge discovery } \\
\text { and creation. } \\
\text { Oy company possesses the system to collect various } \\
\text { Successful and failed experience. }\end{array}$ & .951 \\
\end{tabular}




\section{Conclusion}

This study focused on testing the validity and reliability of the tool that will be widely used in the actual study. The conclusions reached in this study relate to the statistical results obtained. Therefore, the effects of the variables under study will be determined after the actual study. Data were collected on a small scale for the application of the pilot study. Content and face validity have been implemented, which led to the change and replacement of a set of paragraphs. The study also conducted a reliability test for the variables, indicating the reliability of all elements based on the Cronbach alpha test (all of which exceeded 0.70 standards), this means retaining all paragraphs.

\section{References}

Abdelhafiz, I. M., Alloubani, A. M. D., \& Almatari, M. (2016). Impact of leadership styles adopted by head nurses on job satisfaction: a comparative study between governmental and private hospitals in Jordan. Journal of nursing management, 24(3), 384-392.

Al-Ababneh, M. (2013). Leadership style of managers in five-star hotels and its relationship with employee's job satisfaction. Journal of Occupational and Organisational Psychology, 3(2), 94.

Ali, S. H., \& Ali, A. F. (2010). A conceptual framework for crisis planning and management in the Jordanian tourism industry. Advances in Management.

Alonderiene, R., \& Majauskaite, M. (2016). Leadership style and job satisfaction in higher education institutions. International Journal of Educational Management, 30(1), 140164.

Alwin, D. F. (2007). Margins of error: A study of reliability in survey measurement (Vol. 547): John Wiley \& Sons.

Amin, M., Khairuzzaman Wan Ismail, W., Zaleha Abdul Rasid, S., \& Daverson Andrew Selemani, R. (2014). The impact of human resource management practices on performance: Evidence from a Public University. The TQM Journal, 26(2), 125-142.

Avolio, B. J., Walumbwa, F. O., \& Weber, T. J. (2009). Leadership: Current theories, research, and future directions. Annual review of psychology, 60, 421-449.

Awang, Z. (2012). Structural equation modeling using AMOS graphic. Penerbit Universiti Teknologi MARA.

Babu, H. R., \& Ramesh, M. (2013). Relationship between job satisfaction and quality of work life of employees in service sector. Perspectives of Innovations, Economics and Business, 13(2), 58-72.

Benjamin, O. A. (2015). Impact of organisational culture and leadership style on quality of work-life among employees in nigera. African journal for the psychological studies of social issues, 18(1), 109-121.

Bin, A. S. (2015). The relationship between job satisfaction, job performance and employee engagement: An explorative study.

Chen, W.-J. (2013). Factors influencing internal service quality at international tourist hotels. International Journal of Hospitality Management, 35, 152-160.

Chiang, F. F., Birtch, T. A., \& Cai, Z. (2014). Front-line service employees' job satisfaction in the hospitality industry: The influence of job demand variability and the moderating roles of job content and job context factors. Cornell Hospitality Quarterly, 55(4), 398407. 
Chiu, S.-F., \& Tsai, W.-C. (2007). The linkage between profit sharing and organisational citizenship behaviour. The International Journal of Human Resource Management, 18(6), 1098-1115.

Damayanthi, H., Wichaikhum, O., \& Chontawan, R. (2014). Predicting factors of job satisfaction among nurses in Sri Lanka. International Journal of Pharmacy \& BioSciences, 1(1).

Evans, J. R., \& Jack, E. P. (2003). Validating key results linkages in the Baldrige performance excellence model. The quality management journal, 10(2), 7.

Gibson, J. L., Ivancevich, J. M., Donnelly, J. H., \& Konopaske, R. (1991). Organisations: Behaviour, structure, processes: Irwin Homewood, IL.

Grant, A. M., \& Parker, S. K. (2009). 7 redesigning work design theories: the rise of relational and proactive perspectives. Academy of Management annals, 3(1), 317-375.

Hair, J. F. J., Black, W. C., Babin, B. J., \& Anderson, R. E. (2014). Multivariate Data Analysis (7th ed.). United State: Pearson Education Limited.

Haksever, C. (2000). Service management and operations: Pearson College Division.

Hamideh, S., Hossein, A., Fatemeh, Z. H., Hassan, M., Kobra, A., \& Hassan, M. S. (2015). The Relation of Organisational Structure and its Dimensions with Staff's Quality of Work Life. American International Journal of Contemporary Research, 5(3), 106-114.

Hayes, A. F. (2017). Introduction to mediation, moderation, and conditional process analysis: A regression-based approach. Guilford Publications.

Iacobucci, D., \& Churchill Jr, G. A. (2010). Marketing Research, 10. Aufl., Mason ua.

Ilyas, M., \& Abdullah, T. (2016). The Effect of Leadership, Organisational Culture, Emotional Intellegence, and Job Satisfaction on Performance. International Journal of Evaluation and Research in Education, 5(2), 158-164.

Judge, T. A., Thoresen, C. J., Bono, J. E., \& Patton, G. K. (2001). The job satisfaction-job performance relationship: A qualitative and quantitative review: American Psychological Association.

Kavanaugh, R. R., \& Ninemeier, J. D. (2007). Supervision in the hospitality industry: American Hotel \& Lodging Educational Institute.

Masa'deh, R. e. (2016). The Role of Knowledge Management Infrastructure in Enhancing Job Satisfaction at Aqaba Five Star Hotels in Jordan.

Mullins, L. J. (1998). Managing people in the hospitality industry: Addison Wesley Longman Higher Education.

Nanjundeswaraswamy, T., \& Swamy, D. (2014). Leadership styles. Advances in Management, $7(2), 57$.

Nazem, F., \& Entezari, M. S. (2014). Prediction of Employee Quality of Work Life Based on The Leadership Styles (Transformational and Transactional) At the Ministry of Education. Indian Journal of Fundamental and Applied Life Sciences, 4(S4), 33653369.

Nunnally, J. C. (1978). Psychometric theory (2nd ed.). New York, NY: McGraw-Hill.

Øgaard, T., Marnburg, E., \& Larsen, S. (2008). Perceptions of organisational structure in the hospitality industry: Consequences for commitment, job satisfaction and perceived performance. Tourism Management, 29(4), 661-671.

Othman, A., \& Mok, C. L. (2009). Relationship between quality of work life (QWL) and job satisfaction: A case Study of enterprise "XYZ" in malacca.

Owolabi, A. B. (2015). Effect of Work-Family Conflict and Job Satisfaction on Quality of Work Life. Advances in Social Sciences Research Journal, 2(2).

Pallant, J. (2010). SPSS survival manual: A step by step guide to data analysis using SPSS. (4th ed., Ed.) (Vol. 2010, p. 352). New York: McGraw Hill International. 
Picardi, C. (2017). Organisational Structure's Relationship to Job Satisfaction: Moderating Effects of Personality. Retrieved 2017, from UB Scholar Works https://scholarworks.bridgeport.edu/xmlui/bitstream/handle/123456789/1836/340FacultyResearchDay2017_CarriePicardiPoster.pdf?sequence=1\&isAllowed=y

Pushpakumari, M. (2008). The impact of job satisfaction on job performance: An empirical analysis. Paper presented at the City Forum.

Robbins, S. P. (2009). Organisational Behavior, 13/E: Pearson Education India.

Rogelberg, S. G., Allen, J. A., Shanock, L., Scott, C., \& Shuffler, M. (2010). Employee satisfaction with meetings: A contemporary facet of job satisfaction. Human resource management, 49(2), 149-172.

Saleem, H. (2015). The impact of leadership styles on job satisfaction and mediating role of perceived organisational politics. Procedia-Social and Behavioral Sciences, 172, 563569.

Salimbahrami, S. H., Ahmadi, H., Hajikolaei, F. Z., Mirzajani, H., Asheghan, K., \& Sahebi, H. M. (2015). The Relation of Organisational Structure and its Dimensions with Staff's Quality of Work Life. American International Journal of Contemporary Research, 3(5), 106-114.

Srivastava, P. (2016). LEADERSHIP STYLES IN WESTERN \& EASTERN SOCIETIES AND ITS RELATION WITH ORGANISATIONAL PERFORMANCE. Pranjana: The Journal of Management Awareness, 19(1).

Tabachnick, B. G., \& Fidell, L. S. (2013). Using Multivariate Statistics (6th ed., pp. 1-983). New Jersey: Pearson Education Inc.

Thomas, O. O. (2015a). EFFECTS OF ORGANISATIONAL STRUCTURE ON JOB SATISFACTION IN THE NIGERIAN FINANCIAL SECTOR: EMPIRICAL INSIGHT FROM SELECTED BANKS IN LAGOS STATE. NG-Journal of Social Development, 5(1).

Tran, Q., \& Tian, Y. (2013). Organisational structure: Influencing factors and impact on a firm. American Journal of Industrial and Business Management, 3(2), 229.

Yadav, R., \& Khanna, A. (2014). Employees' Satisfaction on Quality of Work life at State Bank of India.

Zikmund, W. G., Carr, J. C., Babin, B., \& Griffin, M. (2013). Business research methods. Nelson Education. 